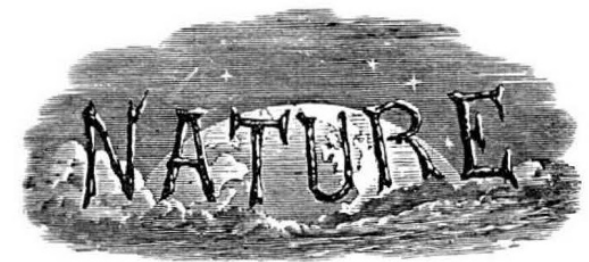

SATURDAY, SEPTEMBER Io, I932

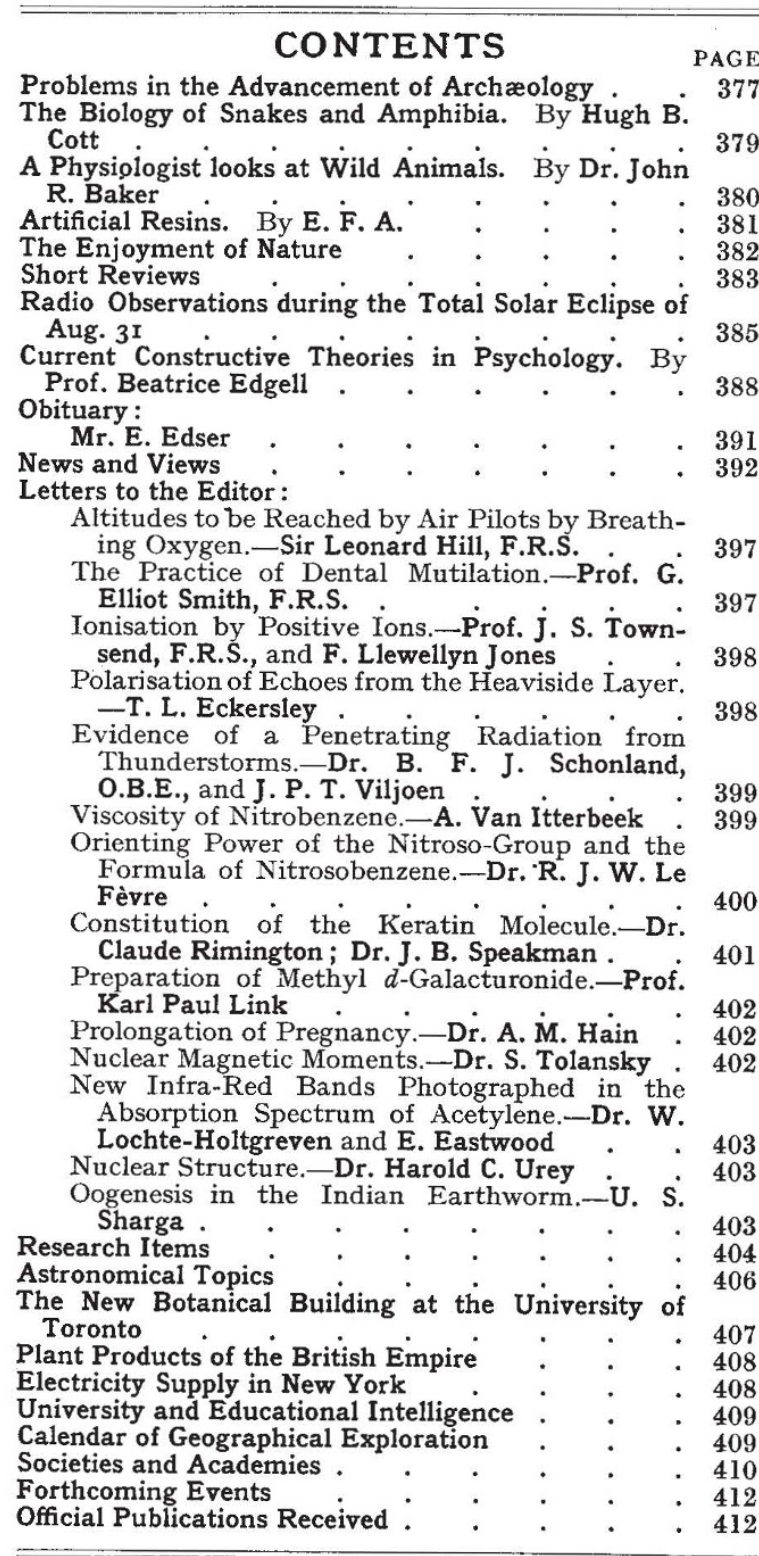

Editorial and Publishing Offices:

MACMILLAN \& CO., LTD.

ST. MARTIN'S STREET, LONDON, W.C.2

Advertisements should be addressed to

T. G. Scott $\&$ Son, Ltd., 63 Ludgate Hill, London, E. C. 4

Telephone Number: City 1266

No. 3280, VoL. 130]

\section{Problems in the Advancement of Archæology}

T $\mathrm{T}$ is some time since anyone so closely identified 1 with field archæology as Dr. Randall-MacIver has presided over 'Anthropology' at an annual meeting of the British Association for the Advancement of Science. It was, therefore, not without wisdom that Dr. Randall-MacIver elected to make in his presidential address a comprehensive survey of the practical problems and relations of archæological science as it stands to-day, rather than to deal with the results of recent research or of some specific investigation. Yet more than the mere passing of time called for some pronouncement on general principles in matters which have seemed to him to require comment. In the last decade archæological method and technique have developed rapidly; while the range of archæological activity has been extended enormously in many directions both in time and space. Areas which were once regarded as widely separated and studied in isolation, are now often viewed as links in a single chain. No longer can the methods and aims of archæological investigation in any country be regarded as of little concern to those who stand outside the national boundary. The field of archæological studies, in fact, has undergone, and is still undergoing, a process of unification which gives a peculiar significance to any pronouncement on the organisation and administration of research which is put forward with the authority of a presidential chair of a section of the British Association.

Dr. Randall-MacIver admitted that to some extent he had been influenced in his choice of subject by the example of his predecessor in the chair. Prof. Radcliffe-Brown last year, it will be remembered, reviewed the methods of field work in ethnography and its relation to the problems in synthesis of the comparative worker. The two branches of investigation in the field have this in common, that they now make heavier demands than ever before on the technical equipment of the investigator. The development of both ethnography and archæology owe much to the amateur; but in neither does investigation stand any longer at the stage at which the field notes or the rough spadework of the passing traveller are likely to make any contribution of lasting value to the respective branch of science in which he is interested. At best they may point the way to the skilled and trained investigator. This is not a question of amateur versus professional-it is to be hoped that research in Great Britain, which owes so much to 
the amateur, will never be debarred to him-but of the trained man, amateur or professional, against the untrained.

In laying it down as a principle which should be universally recognised, that none but a properly accredited and trained archæologist, approved and supported by a group or committee of experts, should be permitted to excavate any site whatsoever, Dr. Randall-MacIver opens up a whole nexus of problems that confront modern archæology and its future development.

The more recent legislation for the protection of ancient monuments in Great Britain admittedly represents a great advance, and has gone some way towards ensuring the skilled excavation of valuable sites. On the other hand, the British Parliament is still sufficiently individualistic in its way of thinking to admit private rights of ownership which are not always in the best interests of the community in the long run, especially when they endanger evidence which might be invaluable to the future archæologist and historian.

Dr. Randall-MacIver's suggestion that part of a site upon which excavations are being made, or are in contemplation, should be set aside for future investigation, after some more or less lengthy period has elapsed, in the light of more fully developed knowledge-a suggestion, by the way, which was made by Sir Flinders Petrie some years ago--is a counsel of perfection which perhaps few investigators would have the strength of mind to follow without the restraint of superior authority behind them. That all, however, are not without some measure of self-denial in the face of posterity is indicated by the recent example of Mr. Alexander Keiller, at Windmill Hill, who, as recently announced, has reserved part of his valuable Early Bronze Age site for a future generation.

The practice of different countries in relation to their ancient monuments is far from uniform. Nor can it be said that vigilance is exercised everywhere in an equal degree in securing the observance of regulations. In some cases legislation, excellent in intention, fails in its object through laxity in translating its provisions into action. France, for example, would appear a case in point, at least until recently, according to the statement of French archæologists themselves. In this connexion, and in addressing a warning of the dangers ahead to those countries in which archæological investigation has scarcely attained the stage even of infancy, Dr. Randall-MacIver has two interesting suggestions to offer. One, an international question, is the formation of something in the nature of an archæo- logical Court of Appeal-a scientific League of Nations; and the other, a concern of each country individually, but of enormous moment to archæological science at large, deals with control of the sale of antiquities-one of the strongest incentives to the private owner's destructive activities. Both classes of problem are difficult enough, though on paper it is perhaps the lesser which presents the greater difficulty in the tangle of conflicting interests impeding any straightforward solution.

It is not to the purpose here to enumerate or discuss the many problems of State regulation of archæological investigation on a nationalist basis. They are many and varied. That, in the interests of the advancement of archæological science, uniformity in dealing with them, according to the most advanced knowledge of the day, is urgently demanded, is a matter of common opinion in archæological circles. The suggestion of an archæological League of Nations, perhaps, may have reminded some of Dr. Randall-MacIver's audience of the relation of the League of Nations to matters other than political, and of the existence of a Committee for Intellectual Co-operation. On the other hand, a body less cumbrous to move and in closer touch with the actual situation in many, if not all, of its aspects, is the recently inaugurated International Congress of Prehistoric Sciences, which, although it will come into existence at intervals only, has provided, by the institution of research committees, a machinery for at least the initial stages of exploration of the problem.

The difficulty of dealing with the sale of ' curios ' to the collector lies at the root of the greater number of the unauthorised or unskilful exploitations of the sites of antiquity. Were it possible to divert the stream of gold which pours into the pockets of the unscruprlous dealer, much of the destruction of valuable evidence which goes on, especially in the East, would cease automatically. On the other hand, the institution of official ' curio' shops for the sale of museum duplicates on the lines of that in Egypt, to which Dr. Randall-MacIver referred, to be effective would have to be a monopoly, and while it certainly would add materially to the revenue of the museums, which are neverat least, on the basis of their own calculationsliberally financed, would open the way to a number of abuses which it would be difficult to check. In Great Britain, the more liberal law of treasure trove, a genuine, if restricted, interest in the origin and history of finds among the artisan and agricultural classes, and the system of the loan of duplicates by the museums, meet the more serious

No. 3280 , VoL. 130] 
difficulties which Dr. Randall-MacIver has in mind. It must be admitted, however, that only rarely in Great Britain do we find antiquities of sufficient intrinsic value or of such obvious interest as to tempt the unscrupulous. But Great Britain's support, if only through the wide geographical distribution of her archæological interests, would be a potent factor in securing action on a common basis in those countries in which the question is one of more vital concern. May we add that the creation of a conscience in the collector offers a field for missionary effort to the ardent archæologist.

Dr. Randall-MacIver is no respecter of persons in his criticism, and he does not hesitate to chide the museums which press their excavators for impressive specimens to add to their collections, without thought of the value of the insignificant (in the museum display sense) for the purposes of science. In this matter we should perhaps recognise extenuating circumstances for those museums which must depend for their existence on the generosity of subscribers.

In connexion with museum excavations, reference was made to what, from the archæologist's point of view, is an evil almost equally grave-the delay in publication of results, a fault to which not archæological institutions alone are prone. It is impossible to say how far delay in making available material for comparative study may have hampered advance in archæological studies. The example of Sir Flinders Petrie, who for many years has made it an invariable rule to publish his results within the shortest time possible after his return to England in each year, shows that this is no impossible ideal, in so far as nothing more than a record of facts observed is required of the excavator in the first instance. A time limit for initial publication might well be a condition of any permit to excavate.

Dr. Randall-MacIver's presidential address raises so many points of broad general, as well as specialist, interest, that the commentary might well outrun the text in length, and yet not be exhaustive. Nothing, for example, has been said of his views on the relation of archæology as a science to other branches of the study of man. Yet to the archæologist of the future this offers both a guide and a warning. Unless the study, one of well-defined and rigid limitations in method, be followed in the spirit which Dr. Randall-MacIver advocates, a spirit of liberal co-operation with other disciplines, it risks a specialisation as arid and as sterile as the antiquarianism it has superseded. Of this, however, with our present school of workers in the field, there is little danger.

$$
\text { No. } 3280 \text {, VoL. 130] }
$$

\section{The Biology of Snakes and Amphibia}

(1) The Biology of the Amphibia. By Dr. G. Kingsley Noble. (McGraw-Hill Publications in the Zoölogical Sciences.) Pp. xiii +577 . (London: McGraw-Hill Publishing Co., Ltd., 1931.) $30 s$. net.

(2) Snakes of the World. By Dr. Raymond L. Ditmars. Pp. $x i+207+85$ plates. (New York: The Macmillan Company, 1931.) 30s. net.

(1) $\mathrm{T}$ recent years marked changes have taken place in the outlook of biologists. Zoology must inevitably rest upon a foundation of morphology and classification; yet it is being increasingly realised that the study of animals demands for its development more fertile ground than is presented by the facts of anatomy and phylogeny. The living animal is a side of zoology which dominates to-day. Dr. Kingsley Noble strikes a distinctively modern note in the work under notice in directing attention to the physiological aspect of the subject, and he has been successful in covering the dry bones of anatomy with living flesh.

Part I. (458 pages) gives a well-balanced picture of the structure, physiology, and ecology of the various groups of Amphibia, which are considered in relation to one another and to their environment. The opening chapters deal with general problemsamphibian ancestry, the mechanics of development, evolution, and adaptation. The reader will early realise that within the limits of the class the wide variety of modifications in larval and adult forms is remarkable : members of various families have taken independently to the land for breeding purposes, and we find unrelated forms adapted respectively for crawling, swimming, leaping, burrowing, climbing, parachuting-examples of convergence which have in the past done much to confuse systematists in their attempt to arrive at a natural classification. Yet, as Dr. Noble shows in a survey of life histories (Chap. iii.), larval modifications and nursing habits frequently serve as an important guide to the affinities of species : thus the closely related Phyllobates and Dendrobates (formerly placed in separate families) are the only genera in which the males are known to carry the tadpoles on their backs.

A series of chapters on the structure and function of the vascular, digestive, nervous, and other systems considers each in some detail. Here there is a good section on the endocrine glands, embodying the result of much recent research on the important rôle played by hormones in the physiology of development, and it is interesting to note the 